\title{
HUBUNGAN KADAR HbA1c DENGAN KADAR PROFIL LIPID PADA PASIEN DIABETES MELLITUS TIPE 2 DI POLIKLINIK ENDOKRIN \& METABOLIK RSUP PROF. DR. R. D. KANDOU MANADO
}

\author{
${ }^{1}$ Glorya Stevani Cicilia Loei
}

${ }^{2}$ Karel Pandelaki

${ }^{3}$ Veny Mandang

Bagian Ilmu Penyakit Dalam Fakultas Kedokteran Universitas Sam Ratulangi Manado

gloryaloei10_185@yahoo.com

kpandelaki@yahoo.com

venymandang@gmail.com

\begin{abstract}
Diabetes mellitus now really been treading worldwide era, and became the world's health problems. The main findings the study of diabetes by the Diabetes Control and Complications Trial (DCCT) has showed the importance of HbA1c. The study showed that reduce unemployment $\mathrm{HbA1c}$ can delay or prevent chronic complications. The purpose of this research is to know is there any relationship between HbA1c levels with the levels of lipid profile in type 2 DM patients. The method used in this study is a retrospective observational analytic by approach cross sectional using secondary data. The total sample of 36 patients seeking treatment at the Polyclinic Endocrine and Metabolic RSUP Prof. Dr. R. D. Kandou in Manado the period November 2012 - November 2013. The results of the analysis using Chi Square test shows that there are positive correlation between HbA1c levels with the levels of total cholesterol, LDL, HDL and Triglyceride levels but statistically not significant. Seeing the results, patients with type 2 diabetes have to do with good glycemic control. In order for the complications that occur can be prevented.
\end{abstract}

Keywords: Type 2 Diabetes Mellitus, HbA1c, Lipid Profile

Abstrak: Diabetes mellitus kini benar- benar telah menapaki era kesejagatan, dan menjadi masalah kesehatan dunia. Temuan utama studi diabetes oleh Diabetes Control and Complication Trial (DCCT) telah menunjukan pentingnya tes HbA1c. Studi menunjukan 
bahwa menurunkan angka HbA1c dapat menunda atau mencegah komplikasi kronik. Tujuan penelitian ini adalah untuk mengetahui adakah hubungan antara kadar HbA1c dengan kadar profil lipid pada pasien DM tipe 2. Metode penelitian yang digunakan bersifat retrospektif observasional analitik dengan pendekatan potong lintang menggunakan data sekunder. Jumlah sampel sebanyak 36 pasien yang berobat di Poliklinik Endokrin dan Metabolik RSUP Prof. Dr. R. D. Kandou Manado periode November 2012 - November 2013. Hasil analisis menggunakan uji Chi Square menunjukan bahwa ada korelasi positif antara kadar HbA1c dengan kadar Kolesterol Total, kadar LDL, kadar HDL dan kadar Trigliserida namun hubungannya tidak signifikan. Melihat hasil yang ada, penderita DM tipe 2 harus melakukan kontrol glikemik dengan baik. Agar komplikasi- komplikasi yang bisa saja terjadi dapat kita cegah.

Kata Kunci: Diabetes Mellitus Tipe 2, HbA1c, Profil Lipid

Diabetes mellitus kini benar- benar telah menapaki era kesejagatan, dan menjadi masalah kesehatan dunia. ${ }^{1}$ Dimana secara global, diabetes adalah penyebab kematian 4,6 juta orang pada tahun 2011. ${ }^{2} \quad$ Perserikatan BangsaBangsa (WHO) menyatakan bahwa saat ini 347 juta orang mengidap diabetes. WHO juga memprediksikan, diabetes akan menjadi penyebab utama kematian ke tujuh pada tahun $2030 .^{3}$

Menurut penelitian yang dilakukan oleh Badan Penelitian dan Pengembangan Kesehatan Departemen Kesehatan RI, untuk prevalensi penyakit DM di Indonesia sendiri terdapat 17 provinsi yang mempunyai prevalensi DM lebih tinggi dari angka nasional. ${ }^{4}$ Untuk kota Manado berdasarkan hasil penelitian, menunjukan sebaran prevalensi DM tipe 2 sampai 6,1\%. ${ }^{5}$ Sedangkan pada lansia angkanya mencapai 22\%. ${ }^{6}$ Penelitian yang dilakukan oleh Badan Penelitian dan Pengembangan Kesehatan Departemen Kesehatan RI, juga menunjukan bahwa prevalensi penyakit DM lebih tinggi di daerah perkotaan. $^{4}$

Asupan makanan berlebihan dan/ atau penurunan pengeluaran energi menimbulkan keseimbangan energi positif. Keseimbangan energi positif yang terjadi dari asupan makanan berlebihan terutama berasal dari kelebihan asupan energi dan sumber karbohidrat, sehingga terjadi akumulasi lemak berlebihan di jaringan adipose abdominal. ${ }^{7}$ Adiposit jaringan lemak ini adalah adiposit berukuran besar, kurang peka terhadap kerja antilipolisis sehingga lebih mudah dilipolisis yang menyebabkan peningkatan kadar asam lemak bebas. Selain itu jaringan lemak ternyata menghasilkan beberapa sitokin dan hormon yang menghambat kerja insulin. ${ }^{7}$

Hormon insulin merupakan regulator penting pada metabolisme karbohidrat, lipid dan protein, maka setiap gangguan aksi insulin akan menimbulkan konsekuensi metabolik yang tampak pada sindroma metabolik. ${ }^{7}$ Tindakan pengendalian DM sangat diperlukan, khususnya dengan mengusahakan tingkat gula darah sedekat mungkin dengan normal, merupakan salah satu usaha pencegahan yang terbaik terhadap kemungkinan berkembangnya komplikasi dalam jangka panjang. ${ }^{8}$

Temuan utama studi diabetes oleh Diabetes Control and Complication Trial (DCCT) telah menunjukan pentingnya tes HbA1c. Studi menunjukan bahwa menurunkan angka HbA1c dapat 
menunda atau mencegah komplikasi kronik. ${ }^{8}$ HbA1c merupakan hemoglobin yang dibentuk oleh penempelan non enzimatik glukosa pada kelompok amino $\mathrm{N}$-terminal dari hemoglobin A rantai $\beta{ }^{9}$ Kadar normal HbA1c adalah < 6,5 \%. ${ }^{5}$

\section{METODOLOGI}

Metode yang digunakan dalam penelitian ini bersifat retrospektif observasional analitik dengan pendekatan cross sectional, menggunakan data sekunder (catatan medik) pasien yang berobat di Poliklinik Endokrin dan Metabolik RSUP Prof. Dr. R. D. Kandou Manado periode November 2012 November 2013. Populasi dari penelitian ini adalah penderita Diabetes Mellitus yang ada di RSUP Prof. Dr. R. D. Kandou Manado. Untuk sampel dari penelitian ini adalah penderita Diabetes Mellitus Tipe 2 yang ada di RSUP Prof. Dr. R. D. Kandou Manado sejak 1 November 2012 - 31 November 2013 yang memenuhi kriteria inklusi diantaranya: penderita DM Tipe 2 dan memiliki data HbA1c dan Profil Lipid.

Untuk kriteria eksklusi terdiri dari: penderita DM tipe 2 yang anemia, penderita DM tipe 2 yang sedang hamil, penderita DM tipe 2 dengan eLFG $<70$ $\mathrm{ml} / \mathrm{min} / 1,73 \mathrm{~m}^{2}$. Variabel penelitian terbagi atas dua yakni variabel bebas (independent) yaitu kadar HbA1c dan variabel terikat (dependent) yang terdiri atas kadar Kolesterol Total, kadar LDL, kadar HDL, Kadar Trigliserida. Data yang diperoleh selanjutnya dianalisis dengan uji Chi Square yang menggunakan program SPSS.

\section{HASIL}

Analisis univariat untuk karakteristik umum sampel penelitian meliputi jenis kelamin, usia, HbA1c, kolesterol total, LDL, HDL dan trigliserida. Dari 36 data yang ada terdapat 19 orang perempuan dan 17 orang laki- laki. Usia subjek penelitian bervariasi mulai dari 23 - 70 tahun, dengan rerata 49,44 tahun. Kadar HbA1c mulai dari 3,20\% - 13,90\%, dengan rerata 8,7167\%. Kadar Kolesterol Total mulai dari 139 mg/dL - 297 mg/dL, dengan rerata 210,194 mg/dL. Kadar LDL mulai dari 46,00 mg/dL - 221,00 $\mathrm{mg} / \mathrm{dL}$, dengan rerata $131,4833 \mathrm{mg} / \mathrm{dL}$.

Kadar HDL mulai dari 6,00 mg/dL 76,00 mg/dL, dengan rerata 45.7111 mg/dL. Kadar Trigliserida mulai dari 23,00 mg/dL - 563,00 mg/dL, rerata 137,9444 mg/dL. Nilai Hemoglobin (Hb) mulai dari 12,30 g/dL - 17,80 g/dL, rerata $14,5139 \mathrm{mg} / \mathrm{dL}$. Kadar Serum Kreatinin mulai dari $0,50 \mathrm{mg} / \mathrm{dL}-1,30 \mathrm{mg} / \mathrm{dL}$, rerata $0,8389 \mathrm{mg} / \mathrm{dL}$. Kadar eLFG mulai dari $70,47 \mathrm{~mL} / \mathrm{min} / 1,73 \mathrm{~m}^{2}-137,65$ $\mathrm{mL} / \mathrm{min} / 1,73 \mathrm{~m}^{2}$, rerata $94,8947 \mathrm{~mL} / \mathrm{min} /$ $1,73 \mathrm{~m}^{2}$. Untuk lebih jelas, dapat dilihat pada tabel di bawah ini:

Tabel 1. Karakteristik Umum Sampel Penelitian

\begin{tabular}{lccc}
\hline Variabel & N & Min - Maks & Rerata \\
\hline Jenis Kelamin: & & & \\
Perempuan & 19 & & \\
Laki- laki & 17 & & 49,44 \\
Usia (Tahun) & 36 & $23-70$ & \\
HbA1c (\%) & 36 & $3,20-13,90$ & 8,7167 \\
Profil Lipid: & & & \\
Kolesterol Total (mg/dL) & 36 & $139-297$ & 210,194 \\
LDL (mg/dL) & 36 & $46,00-221,00$ & 131,4833 \\
\hline
\end{tabular}




\begin{tabular}{lrcl}
\hline HDL (mg/dL) & 36 & $6,00-76,00$ & 45,7111 \\
Trigliserida (mg/dL) & 36 & $23,00-563,00$ & 137,9444 \\
Hemoglobin (g/dL) & 36 & $12,30-17.80$ & 14,5139 \\
Serum Kreatinin (mg/dL) & 36 & $0,5-1,30$ & 0,8389 \\
eLFG (ml/min/1,73 m²) & 36 & $70,47-137,65$ & 94,8947 \\
\hline
\end{tabular}

Analisis Bivariat yang digunakan adalah uji Chi Square dengan terlebih dahulu mentransform data nominal menjadi data ordinal, sehingga untuk menganalisis hubungan kadar HbA1c dengan kadar Kolesterol Total, kadar LDL, kadar HDL, dan dengan kadar trigliserida digunakan uji Chi Square.

Untuk pengujian hubungan $\mathrm{HbA1c}$ dengan Kolesterol Total, nilai korelasi yang diperoleh adalah 0,227 (korelasi positif). Perolehan $\mathrm{p}$ hitung $=1,461^{\mathrm{a}}>$ 0,05 yang menandakan bahwa tidak ada hubungan yang signifikan antara kadar HbA1c dengan kadar Kolesterol total.

Tabel 2. Pengujian Hubungan HbA1c dengan Kolesterol Total

\begin{tabular}{|c|c|c|c|}
\hline & Value & $\overline{\text { df }}$ & $\begin{array}{c}\text { Asymp. Sig. } \\
\text { (2-sided) }\end{array}$ \\
\hline Chi Square & $1.461^{\mathrm{a}}$ & 1 & .227 \\
\hline Continuity Correction $^{\mathbf{b}}$ & .716 & 1 & .397 \\
\hline Likelihood Ratio & 1.514 & 1 & .219 \\
\hline Linear-by-Linear Association & 1.420 & 1 & .233 \\
\hline $\mathrm{N}$ of Valid Cases & 36 & & \\
\hline
\end{tabular}

Nilai korelasi yang didapatkan untuk pengujian hubungan antara kadar HbA1c dengan kadar LDL adalah 0,733 (korelasi positif). Perolehan $\mathrm{p}$ hitung $=0,116^{\mathrm{a}}>$ 0,05 yang menandakan bahwa tidak ada hubungan yang signifikan antara kadar HbA1c dengan kadar LDL.

Tabel 3. Pengujian Hubungan HbA1c dengan LDL

\begin{tabular}{|c|c|c|c|}
\hline & Value & df & Asymp. Sig. (2-sided) \\
\hline Chi Square & $.116^{\mathrm{a}}$ & 1 & .733 \\
\hline Continuity Correction ${ }^{\mathrm{b}}$ & .000 & 1 & 1.000 \\
\hline Likelihood Ratio & .113 & 1 & .736 \\
\hline Linear-by-Linear Associatiol & .113 & 1 & .737 \\
\hline $\mathrm{N}$ of Valid Cases & 36 & & \\
\hline
\end{tabular}

Hasil yang didapatkan dari analisa hubungan HbA1c dengan HDL ini adalah nilai korelasinya 0,473 (korelasi postif). Untuk perolehan $\mathrm{p}$ hitung $=0,514^{\mathrm{a}}>0,05$ yang menandakan bahwa tidak ada hubungan yang signifikan antara kadar HbA1c dengan kadar HDL.

Tabel 4. Pengujian Hubungan HbA1c dengan HDL

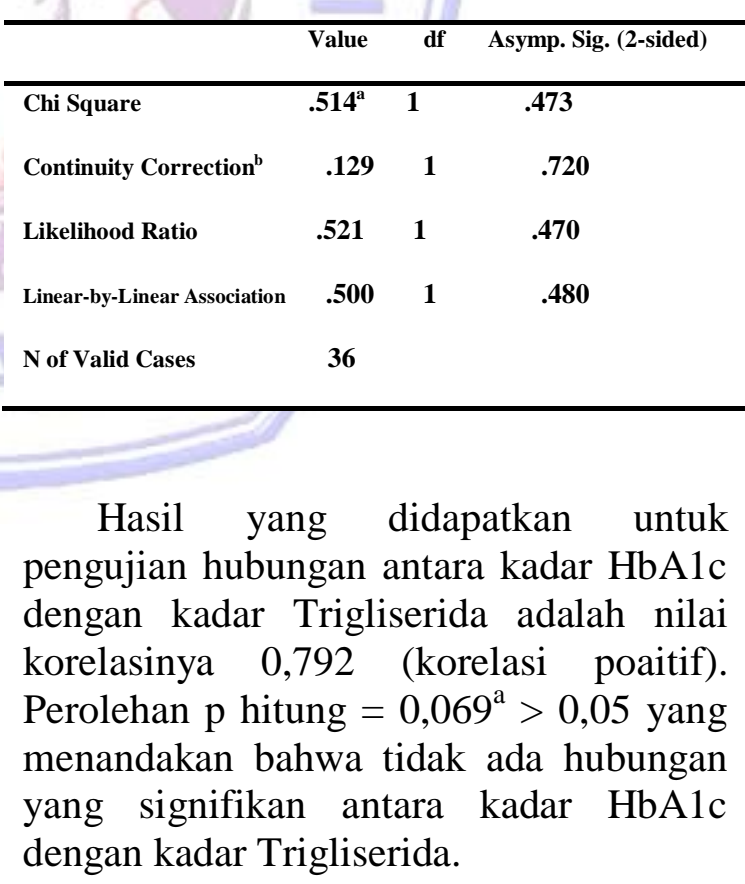


Tabel 5. Pengujian Hubungan HbA1c dengan Trigliserida

\begin{tabular}{|c|c|c|c|}
\hline & Value & df & Asymp. Sig. (2-sided) \\
\hline Chi Square & $.069^{a}$ & 1 & .792 \\
\hline Continuity Correction $^{\text {b }}$ & .000 & 1 & 1.000 \\
\hline Likelihood Ratio & 0.70 & 1 & .791 \\
\hline Linear-by-Linear Association & .067 & & .795 \\
\hline $\mathrm{N}$ of Valid Cases & 36 & & \\
\hline
\end{tabular}

\section{PEMBAHASAN}

Berdasarkan hasil dari penelitian yang telah di laksanakan di Poli Endokrin Metabolik Bagian Ilmu Penyakit Dalam RSUP Prof. Dr. R. D. Kandou Manado selama satu bulan dimana 36 data menjadi sampel penelitian, dapat diperoleh gambaran bahwa untuk kategori jenis kelamin, diperoleh jenis kelamin perempuan lebih banyak dibanding jenis kelamin laki- laki. Penelitian yang dilakukan oleh Effendi, Rustam juga menunjukan hasil yang sama. Dimana penderita DM terbanyak adalah yang berjenis kelamin perempuan. ${ }^{10}$ Hal yang sama juga diperoleh Wulan lewat penelitiannya. ${ }^{11}$

Untuk gambaran uji statistik analisis hubungan antara kadar $\mathrm{HbA1c}$ dengan kadar Kolesterol Total, nilai korelasinya adalah 0,227 (korelasi positif). Perolehan $\mathrm{p}$ hitung $=1,461^{\mathrm{a}}>0,05$ yang menandakan bahwa tidak ada hubungan yang signifikan antara kadar HbA1c dengan kadar Kolesterol total.

Hal ini sama dengan penelitian sebelumnya yang dilakukan oleh Singh dan Kumar. Penelitian ini menunjukan bahwa tidak adanya hubungan signifikan antara kadar HbA1c dengan kadar
Kolesterol Total. Namun terdapat hubungan postif antara keduanya. Hal yang sama juga disampaikan Erciyas, dkk yang menyatakan bahwa adanya hubungan positif antara kadar $\mathrm{HbA1c}$ dengan kadar Kolesterol Total. ${ }^{12}$

Untuk uji statistik analisis hubungan antara kadar HbA1c dengan kadar LDL, menunjukan nilai korelasinya 0,733 (korelasi positif). Perolehan $\mathrm{p}$ hitung = $0,116^{\mathrm{a}}>0,05$ yang menandakan bahwa tidak ada hubungan yang signifikan antara kadar HbA1c dengan kadar LDL.

Hal ini relatif sama dengan hasil penelitian yang dilakukan Abdulbari Bener, dkk. Dimana menggambarkan bahwa tidak adanya hubungan yang signifikan antara kadar $\mathrm{HbA1c}$ dengan kadar LDL. ${ }^{13}$

Untuk hasil uji statistik analisis hubungan kadar HbA1c dengan kadar HDL menunjukan adanya korelasi positif antara kadar HbA1c dengan kadar HDL. Dimana nilai korelasinya adalah 0,473 (korelasi positif). Perolehan p hitung $=$ $0,514^{\mathrm{a}}>0,05$ yang menandakan bahwa tidak ada hubungan yang signifikan antara kadar HbA1c dengan kadar HDL.

Penelitian yang dilakukan Singh dan Kumar juga menggambarkan hal yang sama. Dimana penelitian tersebut juga mendapatkan hasil tidak adanya hubungan yang signifikan antara kadar HbA1c dengan kadar HDL. ${ }^{12}$

Untuk hasil uji statistik analisis hubungan kadar HbA1c dengan kadar Trigliserida menunjukan adanya korelasi positif tapi tidak signifikan. Dimana nilai korelasi antara kadar HbA1c dengan kadar Trigliserida adalah 0,792 (korelasi positif), sedangkan perolehan $\mathrm{p}$ hitung $=$ $0,069^{\mathrm{a}}>0,05$ yang menandakan bahwa tidak ada hubungan yang signifikan antara kadar $\mathrm{HbA1c}$ dengan kadar Trigliserida. 
Sebuah penelitian yang di publish oleh UNAND juga menunjukan hasil yang sama dengan penelitian ini. Dimana dari analisis korelasi presentasi HbA1c dengan Kadar Trigliserida pada DM Tipe 2 didapatkan korelasi sangat lemah. Dalam pengertian bahwa dengan meningkatnya presentase HbA1c diikuti oleh peningkatan kadar Trigliserida dalam darah, namun secara statistik tidak terdapat hubungan yang bermakna. ${ }^{14}$

Teori menunjukan bahwa semua bagian lipid seperti Kolesterol Total, LDL, dan Trigliserida akan meningkat secara signifikan pada penderita diabetes. $^{15}$ Temuan dari sebuah study dengan jelas menunjukan bahwa $\mathrm{HbA1c}$ tidak hanya berguna sebagai biomarker jangka panjang kontrol glikemik, tetapi juga prediktor yang baik dari profil lipid. Dengan demikian, pengawasan kontrol glikemik menggunakan HbA1c bisa memiliki manfaat tambahan mengidentifikasi pasien diabetes yang berada pada resiko yang lebih besar dari komplikasi kardiovaskular. ${ }^{16}$

Pasien dengan kontrol glikemik yang kurang baik secara signifikan lebih tinggi kadar kolesterol total dan LDL sedangkan kadar HDLnya kurang. ${ }^{17}$ Teori- teori yang ada tentunya belum sepenuhnya dapat dibuktikan dengan penelitian ini, karena hasilnya cukup berbeda. Hal ini bisa saja disebabkan karena peneliti sudah tidak lagi memantau intervensi pengobatan yang dilakukan oleh para pasien yang datanya menjadi sampel penelitian. Padahal HbA1c merupakan indikator yang baik bagi profil lipid pasien dengan DM tipe 2.

\section{KESIMPULAN}

Berdasarkan hasil penelitian yang dilakukan terhadap data 36 pasien yang berobat di Poliklinik Endokrin dan Metabolik RSUP Prof. Dr. R. D. Kandou Manado, dapat ditarik kesimpulan bahwa terdapat hubungan/ korelasi positif antara kadar HbA1c dengan kadar Profil Lipid dalam hal ini kadar Kolesterol Total, kadar LDL, kadar HDL dan kadar Trigliserida. Namun hubungan/ korelasinya tidak signifikan atau tidak bermakna.

\section{SARAN}

Bagi masyarakat yang tidak atau belum terdiagnosis menderita diabetes, agar dapat mencegah penyakit ini. Bagi pasien diabetes mellitus, harus melakukan kontrol glikemik dengan baik. Agar komplikasi- komplikasi yang bisa saja terjadi dapat kita cegah. Bagi Dinas Kesehatan, diharapkan dapat memberikan penyuluhan tentang bagaimana cara mencegah penyakit Diabetes Melitus, cara pengendaliannya seperti apa, dan komplikasi apa saja yang dapat terjadi pada pasien DM. Bagi peneliti selanjutnya, diharapkan penelitian ini dapat menjadi acuan, dan disarankan untuk meneliti lebih lanjut tentang "Hubungan HbA1c dengan Kadar Profil Lipid” dengan meningkatkan atau memperbesar jumlah sampel.

\section{DAFTAR PUSTAKA}

1. Arisman. Obesitas, Diabetes Mellitus, \& Dislipidemia: Konsep, Teori dan Penanganan Aplikatif. Jakarta: 2010. 
2. Oputa RN, Chinenye S. Diabetes Mellitus: A Global Epidemic With Potential Solutions. African Journal of Diabetes Medicine [serial online] 2012 November; 20 (2): [hal 33]. Diperoleh dari: http://www.africanjournalofdiabetes medicine.com. Diakses tanggal 24 September, 2013.

3. World Health Organization (WHO). Media Center Diabetes. Diperoleh dari: http://www.who. int/ index.html. Diakses tanggal 14 Oktober, 2013.

4. RISKESDAS.Jakarta: Litbangkes: 2007

5. PERKENI.Konsensus Pengelolaan dan Pencegahan DM Tipe 2. Jakarta: 2011

6. Unpublished

7. Jalal F, Liputo N, Susanti N, Oenzil F. Hubungan Lingkar Pinggang dengan Kadar Gula Darah. Trigliserida, dan Tekanan Darah pada Etnis Minang di Kabupaten Padang Pariaman, Sumatera Barat. Diperoleh dari: repository.unand.ac.id. Diakses tanggal 8 September, 2013

8. Kusniyah Y, Nursiswati, Rahayu U. Hubungan Tingkat Self Care dengan Tingkat HbA1c Pada Klien Diabetes Melitus Tipe 2 di Poliklinik Endokrin RSUP DR. Hasan Sadikin Bandung. Diperoleh dari: pustaka.unpad.ac. id. Diakses tanggal 18 September 2013.

9. Guerin M, Kumpulan Kasus Patologi Klinik: Glukosa, Jakarta: Binarupa Aksara Publisher, 2013. p. 219.

10. Effendi, Rustam. Gambaran Distribusi Penderita Diabetes Melitus Rawat Jalan di Badan RSUD Manna Bengkulu Selatan 1999-2001; Universitas Sumatera Utara. 2012.

11. Wulan Y. Pola Penderita Diabetes Melitus Tipe 2 yang di Rawat Inap di Bagian/SMF Penyakit Dalam RS. Immanuel Bandung Periode Januari
2005 - Desember 2005; Universitas Kristen Maranatha.

12. Singh G, Kumar A: Relationship Among HbA1c and Lipid Profile in Punajbi Type 2 Diabetic Population. India: Punjabi University Patiala; 2011.

13. Abdulbari B, Mahmoud Z, Mohammed D, Abdulla H, Ghazi D, Ammar R. Lipids, Lipoprotein (a) profile and HbA1c Among Arabian Type 2 Diabetic Patients. Biomedical Research: Dept. of Medical Statistic \& Epidemiology, Doha. Dept. Evidence for Populatio Health Unit, School of Epidemiology and Health Sciences, The University of Manchester, UK. Department of Endocrinology, Hamad General Hospital, Doha. Qatar Diabetic Association and Qatar Foundation, Doha, Qatar. Dept. of Laboratory Medicine \& Pathology, Hamad Medical Corporation, Doha, Qatar; 2007 April.

14. Universitas Andalas (UNAND). Hubungan Glycosylated Haemoglobin Terhadap Kadar Adiponektin dan Kadar Trigliserida pada Diabetes Melitus Tipe 2: 2011.

15. Shivanand K.G, Manjunanth M.L, Jeganathan P.S. Lipid Profile and It's Complication in Diabetes Melitus. IJBAR. 2012. Diperoleh dari: http://ijbar.ssjournals.com. Diakses tanggal 15 Januari 2014.

16. Khan H.A, Sobki S.H, Khan S.A. Clinical and Experimental Medicine: Association Between Glycaemic Control and Serum Lipids Profile In Type 2 Diabetic Patients, vol. 7: Springer - Verlag, 2007. p, 24-29.

17. A Momin, P Bankar, $M$ Bhoite. Glycosilated Hemoglobin (HbA1c): Association With Dyslipidemia and Predictor of Cardiovascular Diseases 
in Type 2 Diabetes Melitus Patients [serial online] 2013 May - Jun. Diperoleh dari: http://www.sco pemed.org/. Diakses tanggal 15 Januari 2014.

18. Adm. Kadar HbA1c Mencerminkan Kadar Lipid. Sep. 2011. Diperoleh dari: http://www. pjnhk.go.id/ content/view. Diakses tanggal 17 Januari 2014. 